BMC

Evolutionary Biology

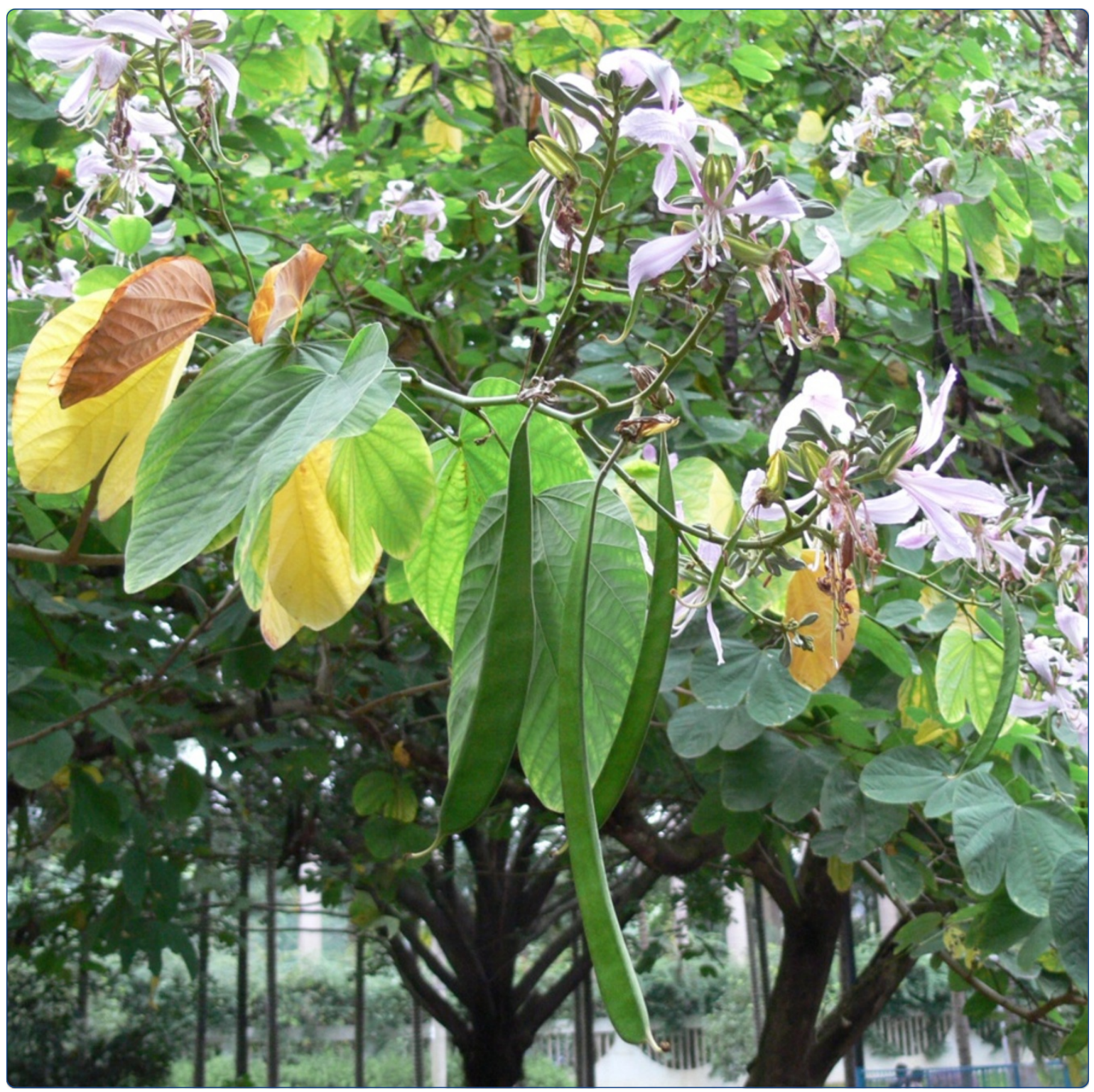

Leaves and fruits of Bauhinia (Leguminosae, Caesalpinioideae, Cercideae) from the Oligocene Ningming Formation of Guangxi, South China and their biogeographic implications

Wang et al.

() Biomed Central 


\title{
Leaves and fruits of Bauhinia (Leguminosae, Caesalpinioideae, Cercideae) from the Oligocene Ningming Formation of Guangxi, South China and their biogeographic implications
}

Qi Wang ${ }^{1 *}$, Zhuqiu Song ${ }^{2}$, Yunfa Chen ${ }^{2 *}$, Si Shen ${ }^{1}$ and Zhenyu Li $i^{*}$

\begin{abstract}
Background: The pantropical genus Bauhinia, along with the northern temperate Cercis and several tropical genera, bear bilobate, bifoliolate, or sometimes unifoliolate leaves, which constitute the tribe Cercideae as sister to the rest of the family Leguminosae based on molecular phylogenetics. Hence, the fossil record of Cercideae is pivotal to understand the early evolution and biogeographic history of legumes.

Results: Three fossil species of Bauhinia were described from the Oligocene Ningming Formation of Guangxi, South China. Bauhinia ningmingensis sp. nov. is characterized by its bifoliolate, pulvinate leaves bearing basal acrodromous primary veins and brochidodromous secondary veins. B. cheniae sp. nov. bears moderately or deeply bilobate, pulvinate leaves, with basal actinodromous primary veins and eucamptodromous secondary veins. $B$. larsenii D.X. Zhang et Y.F. Chen emend. possesses shallowly or moderately bilobate, pulvinate leaves bearing basal actinodromous primary veins and brochidodromous secondary veins, as well as elliptic, stipitate, non-winged, and oligo-seeded fruits. Meanwhile, previously reported Bauhinia fossils were reviewed, and those pre-Oligocene foliage across the world are either questionable or have been rejected due to lacking of reliable evidence for their pulvini or/and basal actinodromous or acrodromous venations. Besides Oligocene leaves and fruits presented here, foliage and/or wood of Bauhinia have been documented from the Miocene-Pliocene of Thailand, India, Nepal, Uganda, and Ecuador.
\end{abstract}

Conclusions: Bauhinia has exhibited a certain diversity with bifoliolate- and bilobate-leafed species in a low-latitude locality-Ningming since at least the Oligocene, implying that the tropical zone of South China may represent one of the centres for early diversification of the genus. The reliable macrofossils of Bauhinia and Cercis have made their debut in the Eocene-Oligocene floras from mid-low latitudes and appeared to lack in the coeval floras at high latitudes, implying a possible Tethys Seaway origin and spread of legumes. However, detailed scenarios for the historical biogeography of Bauhinia and its relatives still need more robust dataset from palaeobotany and molecular phylogeny in future research.

Keywords: Bauhinia, Bifoliolate leaf, Bilobate leaf, Biogeography, Cercideae, Cercis, Eocene, Evolution, Fruits, Legumes, Leguminosae, Low latitude, Ningming Formation, Oligocene, Pulvinus, Tethys Seaway origin, Unifoliolate leaf

\footnotetext{
* Correspondence: happyking@ibcas.ac.cn; chenyunfa@163.com; lizy@ibcas.ac.cn ${ }^{1}$ State Key Laboratory of Systematic and Evolutionary Botany, Institute of Botany, Chinese Academy of Sciences, Beijing 100093, P.R. China

${ }^{2}$ Natural History Museum of Guangxi, Nanning 530012, P.R. China
} 


\section{Background}

Bauhinia L. (Leguminosae Juss., Caesalpinioideae DC.) is a pantropical legume genus with ca.150-300 species, the number of which depends on the demarcation of the genus [1-6] (see Additional file 1). The taxonomy of Bauhinia is especially complicated, and it has been recognized either as a large genus [1-3,5,7-9], or as 8-9 distinct genera $[4,6,10]$ (Figure 1). Although a taxonomical consensus has not been achieved, recent studies on pollen morphology and molecular systematics of Bauhinia have suggested that Bauhinia sensu lato is not monophyletic and should be subdivided into Bauhinia sensu stricto and other independent genera [6,10-13] (Figure 1). Bauhinia is well known for its ornamental shrubs and trees, such as $B$. blakeana Dunn being first chosen as the city flower of Hong Kong, China in 1965. In addition, seeds of $B$. petersiana Bolle are used as a coffee substitute [4]; some species, e.g., B. championii (Benth.) Benth., B. purpurea L., B. tomentosa L., have local pharmacological uses [14-16].

Bauhinia was named after two Swiss botanists, the brothers Jean Bauhin (1541-1613) and Gaspard Bauhin (1560-1624), suggesting a brotherly relationship in its commonly bilobate leaves [4]. Bauhinia, along with a northern temperate genus Cercis L. and several tropical genera, bear bilobate, bifoliolate, or sometimes unifoliolate leaves, which constitute the tribe Cercideae Bronn as sister to the remaining legumes in the molecular phylogenetic trees [17-24]. Bilobate, bifoliolate, or unifoliolate pulvinate leaves with basal actinodromous or acrodromous venations are characteristic for Cercideae [25-27], whereas leaves of other legumes are usually pinnately compound, occasionally trifoliolate or palmate (Figure 1). Hence, well-preserved bilobate, bifoliolate, or unifoliolate pulvinate leaves are easily recognizable in the fossil record and can provide an instrumental evidence for understanding the early evolution and biogeographic history of the Cercideae and the Leguminosae.

The goals of this paper are to (1) investigate and evaluate the fossil record of Bauhinia, with special reference to that of Cercis, by comparing both extinct and extant angiosperms with the similar lobed leaf forms, (2) describe the foliage and fruit fossils from the Oligocene Ningming Formation of Guangxi, South China, and discuss their biogeographic implications.

\section{Methods}

Macrofossils

The fossil foliage and fruits studied in this paper were collected from the Ningming Formation at $22^{\circ} 07.690^{\prime} \mathrm{N}$, $107^{\circ} 02.434^{\prime} \mathrm{E}$ in the western region of Ningming County, Guangxi Zhuang Autonomous Region, South China (Figure 2). The Ningming Formation is primarily shallow lacustrine deposits consisting of gray to dark gray mudstone, light yellow shaly siltstone, and finely grained sandstone. No volcanic rocks and mammals are hitherto found in the Ningming Formation [28], and an absolute age for this formation is therefore unavailable. The Ningming Basin is among the late Palaeogene basins (e.g., mammal-bearing

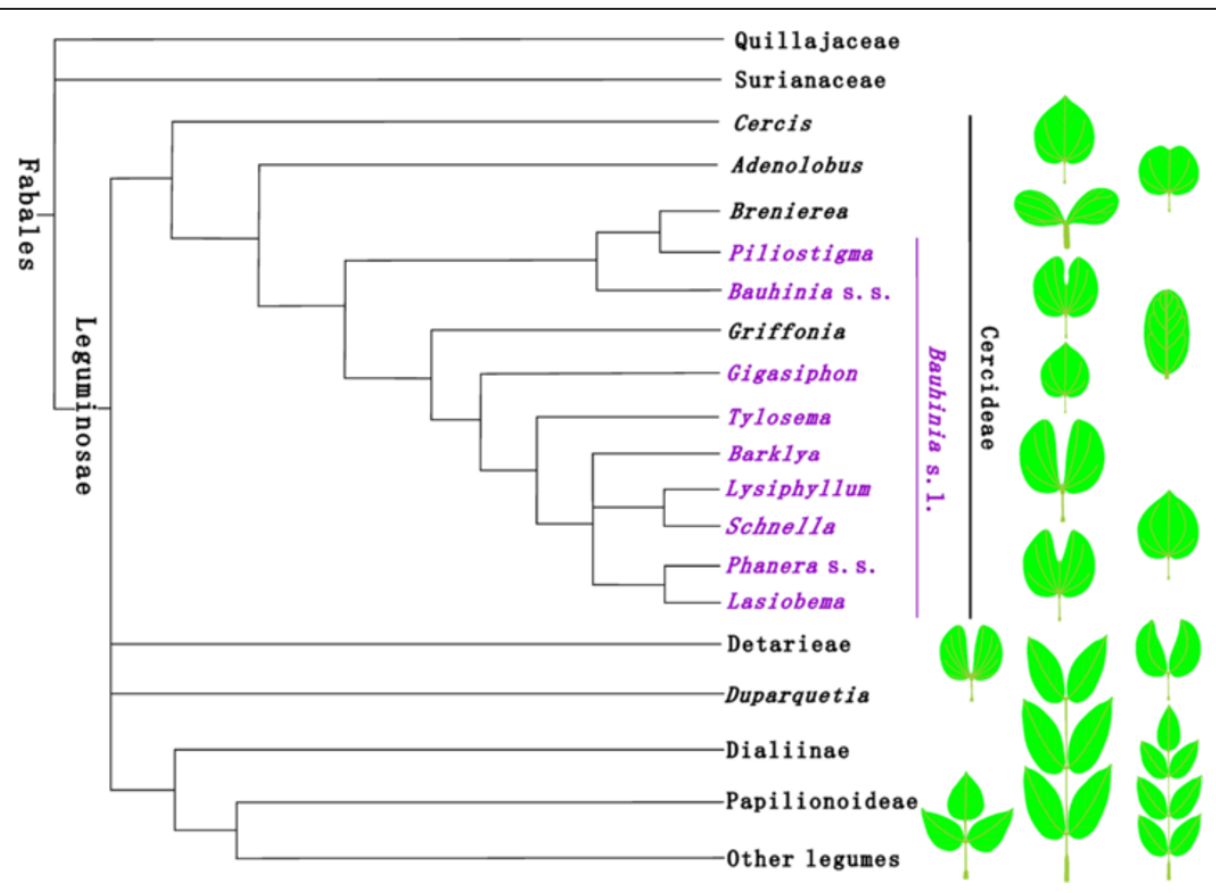

Figure 1 A simplified phylogenetic tree of the Leguminosae, with special reference to the phylogeny of the tribe Cercideae (after $[10,17])$ and iconic leaf forms enhanced. The purple taxa belong to Bauhinia sensu lato. 


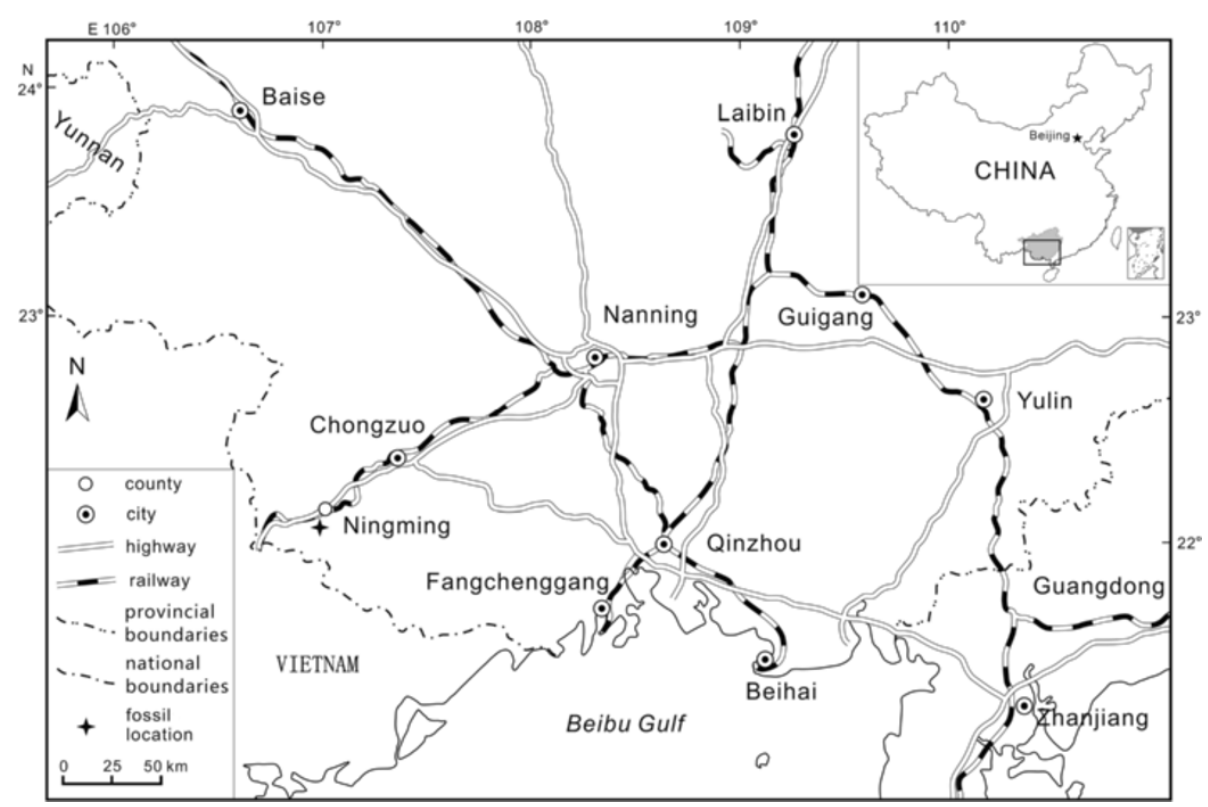

Figure 2 Fossil locality showing Ningming of Guangxi, South China (after [36]).

Na Duong and Bose basins) [29,30] in southern Guangxi and northern Vietnam that experienced a generally similar geological history, so it is inferred that the Ningming Formation is likely to be late Eocene-Oligocene in age. The previous studies on plant macrofossils (e.g., Palaeocarya ningmingensis H.M. Li et Y.F. Chen, P. guangxiensis H.M. Li et Y.F. Chen, Bauhinia larsenii D.X. Zhang et Y.F. Chen, Cephalotaxus ningmingensis G.L. Shi et al., Cupressus guangxiensis G.L. Shi et al., and Calocedrus huashanensis G.L. Shi et al.), sporo-pollen assemblages (e.g., Quercoidites microhenrici (Potonié) Potonié), and fishes (e.g., Ecocarpia ningmingensis G.J. Chen et al., Huashancyprinus robustispinus G.J. Chen et M.M. Chang) from the same locality indicate the Ningming Formation most possibly an Oligocene age [31-39], which is adopted in this paper.

In China, all the land belongs to our country. Our fossil-collecting fieldwork was done in non-National Nature Reserves (NNR) and non-private areas and has been allowed by the local government. We did not violate the Chinese fossil collection and mining laws and management regulations.

The macrofossils are preserved as compressions/impressions only with a little organic material remaining in mudstone. Cuticle preparations were unsuccessful because organic material has been greatly weathered. All the marcofossil specimens used herein are deposited at Natural History Museum of Guangxi (NHMG), Nanning, P.R. China (see Additional file 2).

\section{Herbaria}

The exsiccatae examined in this study are kept at the following herbaria: Chengdu Institute of Biology, Chinese
Academy of Sciences, Chengdu (CDBI), Guangxi Institute of Botany, Chinese Academy of Sciences, Guilin (IBK), South China Botanical Garden, Chinese Academy of Sciences, Guangzhou (IBSC), the Herbarium of Northeast China, Shenyang (IFP), Kunming Institute of Botany, Chinese Academy of Sciences, Kunming (KUN), and the Chinese National Herbarium, Beijing (PE) (see Additional file 2).

\section{Online databases}

(1) eFloras.org [40]. Bauhinia and other living taxa concerned here were consulted (Figure 3; see Additional file 3).

(2) Chinese Virtual Herbarium (CVH) [41]. The images of herbarium specimens were browsed. (3) ILDIS (International Legume Database \& Information Service) [42]. The geographic distribution of living species in Bauhinia is compiled by ILDIS, with a few newly published records (Figure 4; see Additional file 1). (4) Hunt Institute for Botanical Documentation [43]. Standardized abbreviations of plant-family names and periodical titles in this paper were consulted and applied (see References; Additional file 3).

\section{Terminology}

Terms used in the specimen descriptions for leaves and fruits follow Ellis et al. [58]. As for the foliage of the Cercideae, the lower pulvinus has been interpreted as a primary pulvinus at the base of the leaf while the upper pulvinus as a secondary pulvinus homologous with the pulvinus on the leaflet petiolule, consisting of an apical common joint with two distal laminar joints, one for each half of the lamina [25,27,59]. Anatomically, laminar joints are resulted from the tertiary pulvini at the base of 


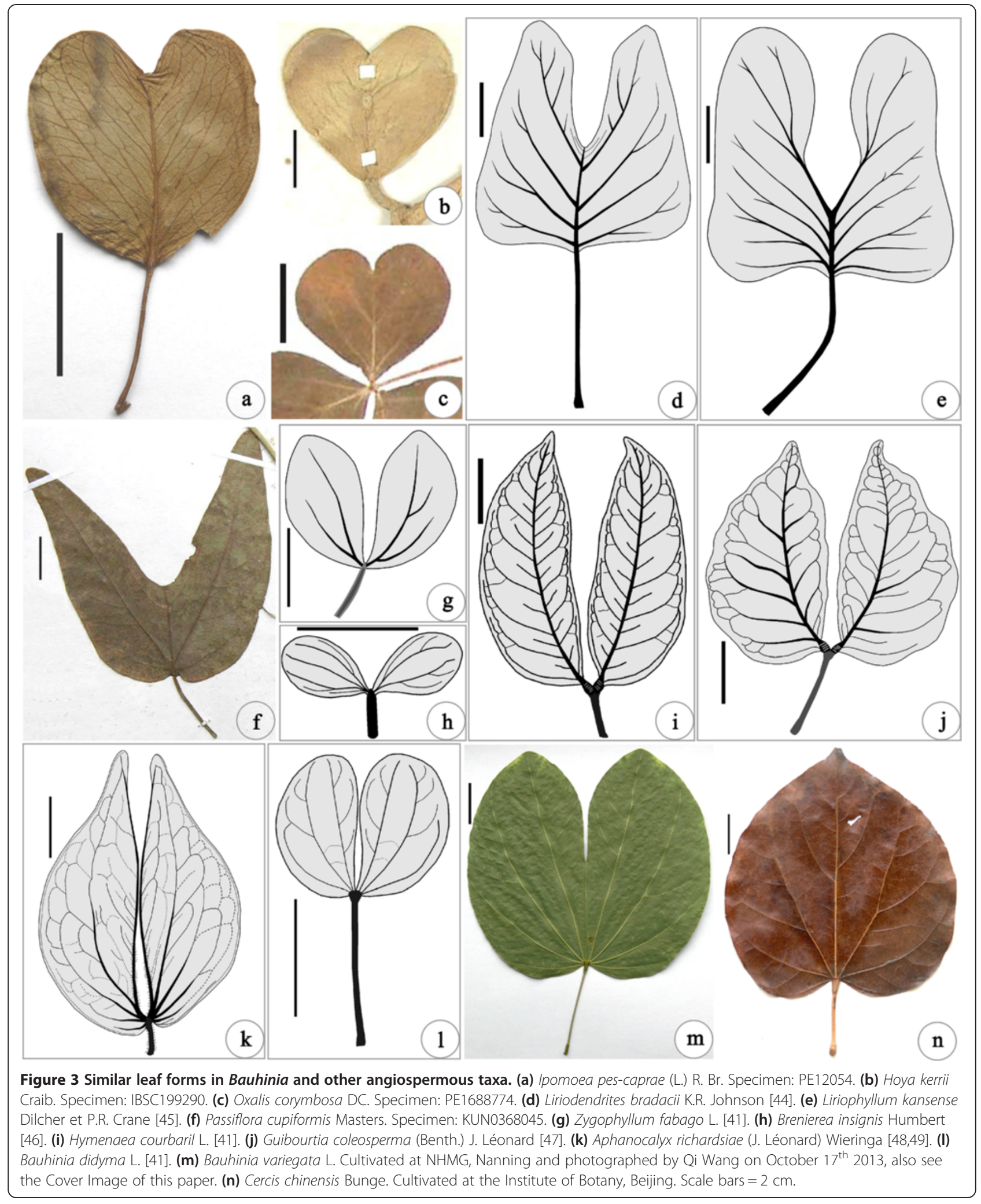

each primary vein [27]. Van der Pijl [25] classified the leaves of Bauhinia into three basic types: unifoliolate, bilobate, and bifoliolate. Cusset [26] subdivided the leaves of the tribe Bauhinieae Benth. into seven types, but unifoliolate, bilobate, and bifoliolate types epitomize in the foliage of living and fossil species of Bauhinia. 


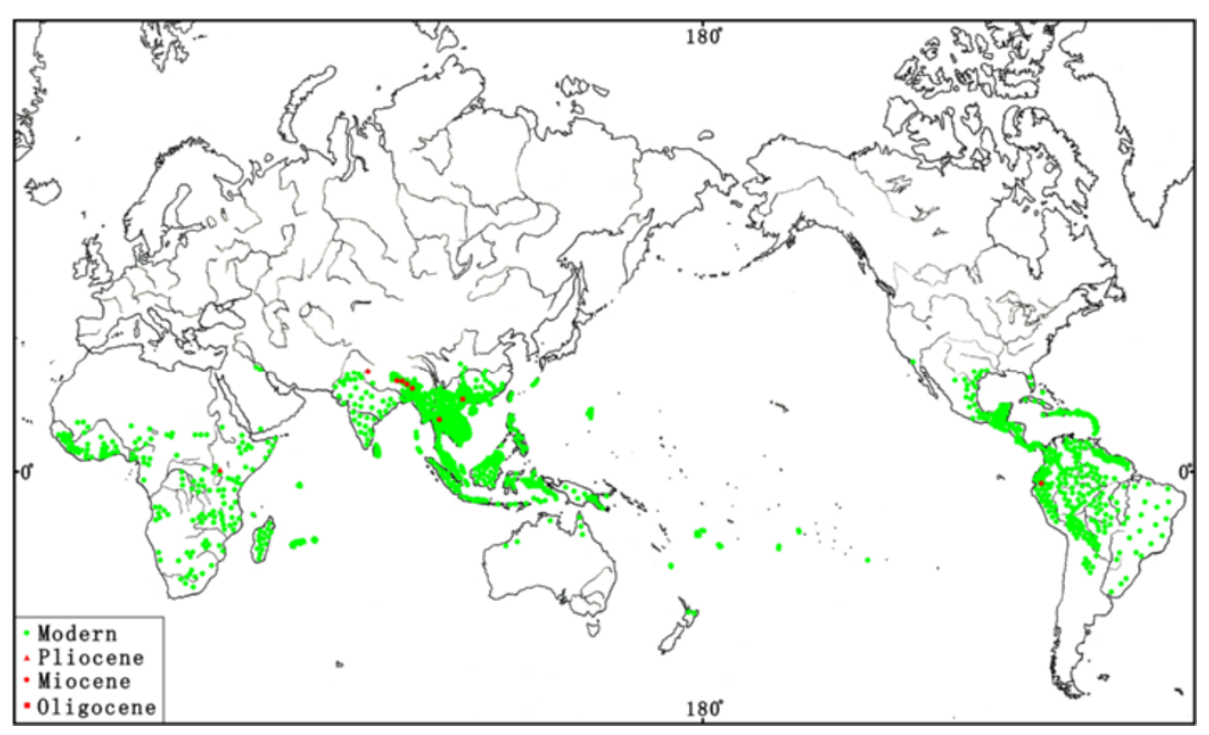

Figure 4 Distributions of modern and fossil Bauhinia L. (The base map drawn by Mr. Sun Yingbao, Institute of Botany, CAS, Beijing). Green dots indicate modern distributions [42]. Red symbols show fossils from the Oligocene-Miocene of China [33], this paper, Ecuador [50], India [51-54], Nepal [55], Thailand [56], and Uganda [57].

Hence, unifoliolate, bilobate, and bifoliolate leaves are adopted herein for the description of Bauhinia foliage. Time calibrations refer to the latest Geologic Time Scale [60]. The global palaeogeographic maps for the Late Cretaceous, Palaeocene, Eocene, and Oligocene were browsed [61].

\section{Comparative morphology}

Both fossil and extant taxa bearing similar unifolioate, bilobate, and bifoliolate leaves in Leguminosae and other families (Figure 3; see Additional file 3) were compared to evaluate the fossil record and biogeographic history of Bauhinia. Based upon an extensive review on the literature and specimens of previously reported Bauhinia and other similar foliage from the Cretaceous and Cenozoic, we summarized the reliable fossil record of Bauhinia (see Additional file 4).

\section{Figures}

Photographs of specimens were taken with digital cameras (Panasonic DMC-FZ30 and Nikon D90). A simplified phylogenetic tree (Figure 1) of the Cercideae within Leguminosae was partially adapted from the literature $[10,17]$, with the iconic leaf forms enhanced. A map for the fossil locality (Figure 2) was partially adapted from the literature [36]. Line drawings of leaf specimens for fossil and living taxa as well as of distributional map of Bauhinia were drawn (Figures 3,4,5,6,7 and 8) and arranged using CorelDRAW 10.0 (Corel, Ottawa, Ontario, Canada) and Adobe Photoshop 6.0 (San Jose, California, USA) programmes.

\section{Abbreviations}

The standardized abbreviations for the family name of plants, the author citation of plant names in this paper and journal titles in References follow Brummitt and Powell [62] as well as Botanico-Periodicum-Huntianum (BPH), its supplement $(\mathrm{BPH} / \mathrm{S})$, and $\mathrm{BPH}-2$ [63], respectively. The herbarium codes refer to Index Herbariorum [64].

\section{Results}

\section{Similar leaf architectural comparisons}

A leaf lamina partially or fully divided into two lobes is not very common but remarkable among angiosperms. Such leaf forms can be traced back to the Late Cretaceous, for example extinct Liriodendron-like angiosperms Liriodendrites bradacii K.R. Johnson [44] and Liriophyllum kansense Dilcher et P.R. Crane [45] (Figure 3d,e), but some of them have been erroneously identified as Bauhinia fossils (see Additional file 4). Overall, both extinct and extant taxa bearing bilobate and bifoliolate foliage occur in Leguminosae, Apocynaceae Juss., Convolvulaceae Juss., Liriodendraceae sensu M.S. Romanov et Dilcher, Oxalidaceae Bercht. et J. Presl, Passifloraceae Juss. ex Roussel, Proteaceae Juss., and Zygophyllaceae R. Br.. In order to determine the reliable fossils of Bauhinia, comparisons are made among both extinct and extant taxa with similar lobed leaf forms (Figure 3; see Additional file 3).

\section{The taxonomy of Bauhinia L.}

The systematics of living Bauhinia L. is primarily based upon growth habit, inflorescence, flower, calyx, hypanthium, petal, fertile stamen number, stamen filament, 


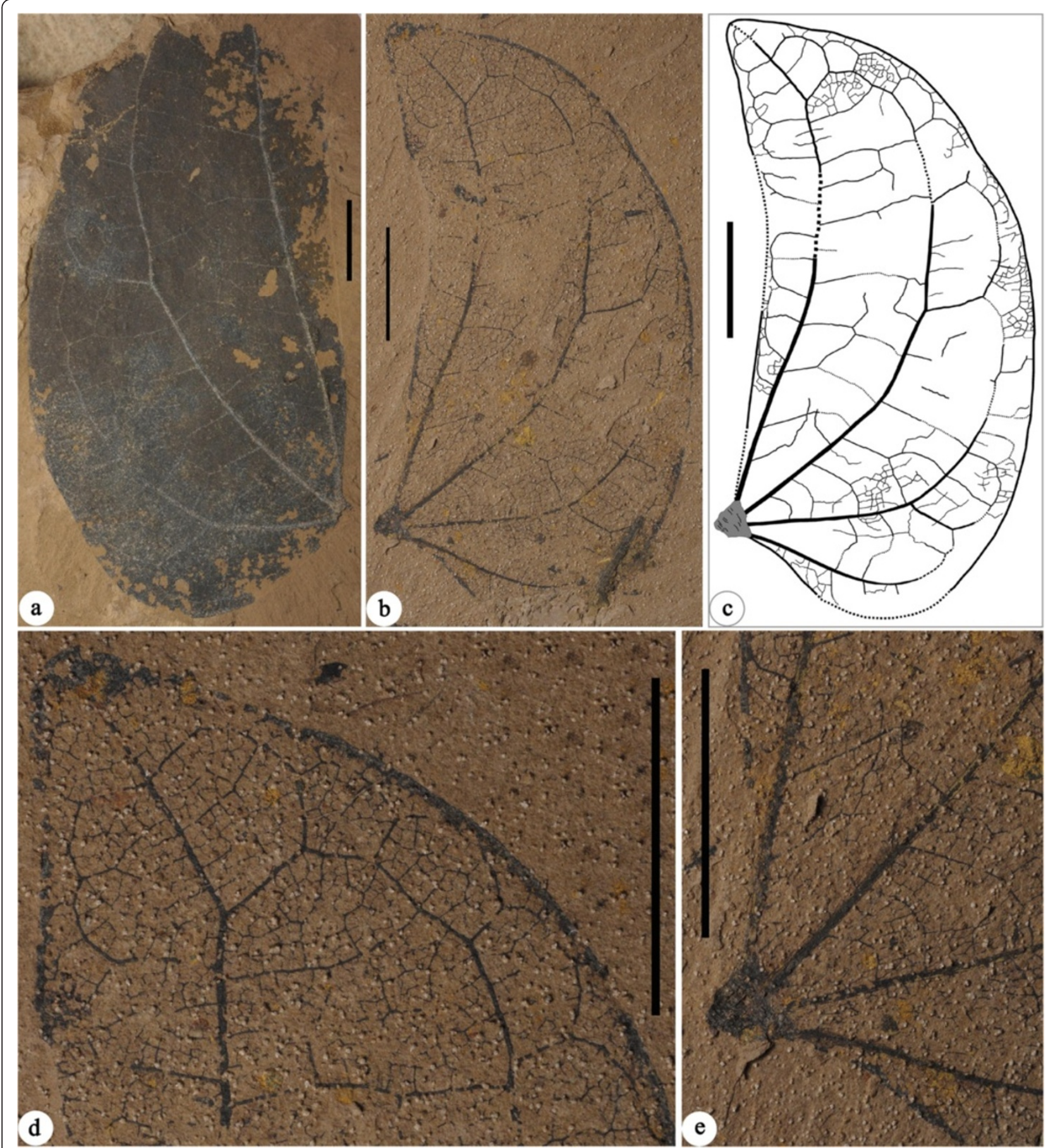

Figure 5 Bauhinia ningmingensis sp. nov. from the Oligocene of Ningming, Guangxi, South China. (a) NHMG 011655 . The foliage apex is not preserved. (b-c) Holotype: NHMG 011654, and its line-drawing, showing the leaf architectural detail. (d) The apex of holotype, showing the higher-order veins. (e) The base of holotype, showing the pulvinate tissue. Scale bars $=1 \mathrm{~cm}$.

gynophore, stigma, pollen, fruit, seed, and leaf morphology $[1-8,12,13]$, as well as molecular data $[9,11]$. Species of Bauhinia sensu stricto are usually trees or shrubs, rarely semi-scandent plants, whereas those of Lysiphyllum (Benth.) De Wit, Schnella Raddi, Tylosema (Schweinf.) Torre et Hillc., and Phanera Lour. (all belonging to Bauhinia sensu lato) are lianas, herbaceous vines or rarely shrubs. Different character combinations in reproductive and vegetative organs have been used to classify Bauhinia sensu lato into Bauhinia sensu stricto and other 7-8 genera, with reference to the molecular phylogenetics of Cercideae $[4,6,10]$ (Figure 1). Bauhinia sensu stricto as one of the first 


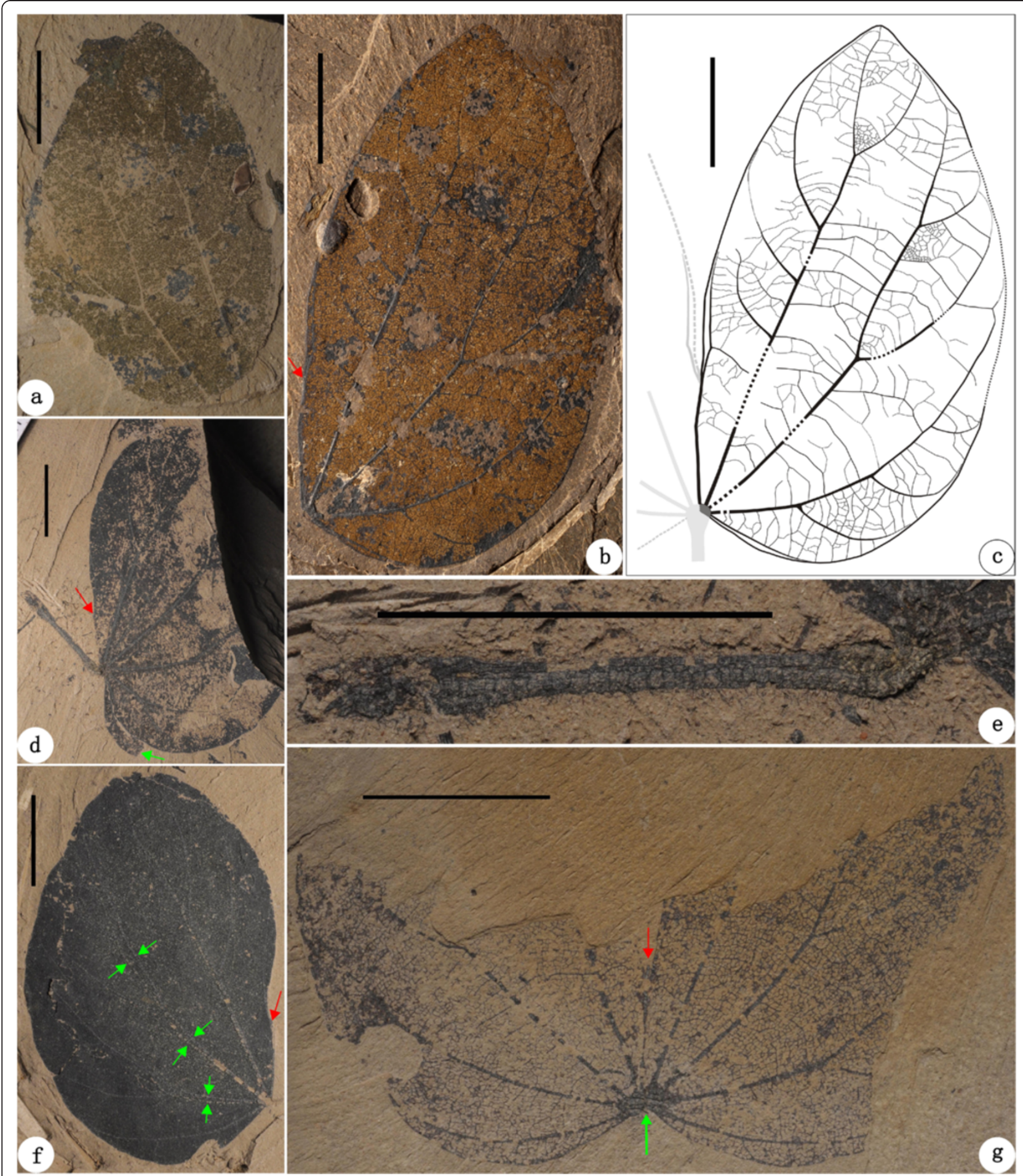

Figure 6 Bauhinia cheniae sp. nov. from the Oligocene of Ningming, Guangxi, South China. (a-b) Holotype: NHMG 011656a, b. Red arrow indicates the position of the sinus. (c) Line-drawing of holotype, showing the leaf architectural detail. (d) NHMG 011657. Red arrow indicates the position of the sinus. Green arrow shows a folded leaf base. (e) Enlargement of the petiole in $\mathbf{d}$, showing thickened upper and lower pulvini as well as dense, spreading hairs. (f) NHMG 011658. Red arrow indicates the position of the sinus. Green arrows indicate partially overlapped primary veins, implying this leaf is folded. (g) NHMG 011659, with the higher-order veins. Red arrow indicates a short spine in the sinus. Green arrow shows a semicircular laminar joint at the leaf base. Scale bars $=1 \mathrm{~cm}$. 


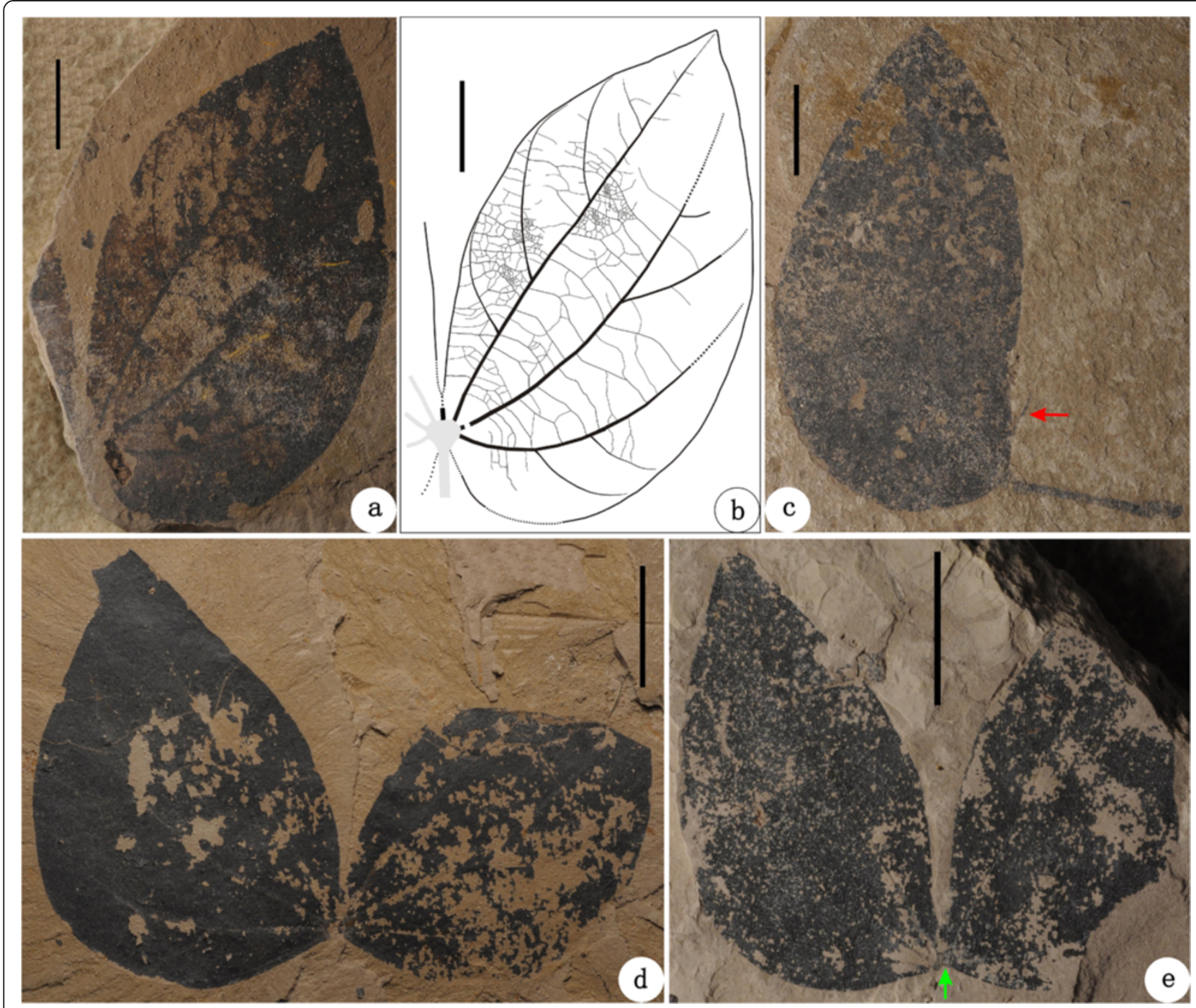

Figure 7 Additional leaves of Bauhinia cheniae sp. nov. from Ningming. (a-b) NHMG 011670, and its line-drawing, showing the leaf architectural detail. (c) NHMG 011671. Red arrow indicates a long spine in the sinus of folded leaf. (d-e) NHMG 011672, 011673, showing two deeply bilobate leaves. Green arrow shows a semicircular laminar joint at the leaf base. Scale bars $=1 \mathrm{~cm}$.

branching lineages is the only pantropical genus in the subtribe Bauhiniinae (Benth.) Walp. of Cercideae, so it may boast an earlier origin and evolutionary history than other relatives within the Bauhiniinae.

Morphological characters are the features that ultimately support the distinctiveness of real biological entities, so integral studies mutually illuminating between morphology and molecular systematics will be key in the discrimination of elusive relationships within Bauhinia sensu lato. However, considerable convergence, parallelism or evolutionary conservativeness in the organs (especially leaves) of Bauhinia sensu stricto and its relatives often place palaeobotanists in a predicament. Without reproductive organs (especially the calyces, fertile stamens, and petals), bilobate leaves of some species in Bauhinia sensu stricto, Phanera, and Schnella would not be distinguished from each other even by neobotanists. Hence, bilobate or bifoliolate leaf fossils in Cercideae were often assigned to Bauhinia sensu lato (see Additional file 4).

The fossil record of Bauhinia and other bilobate leafed taxa Overall, Bauhinia bears mostly bilobate, bifoliolate, or sometimes unifoliolate leaves having characteristic upper and lower pulvini, basal actinodromous or acrodromous primary veins (3-13 in number per leaf), brochidodromous, eucamptodromous or craspedodromous secondary veins, and alternate or opposite percurrent tertiary veins, character combinations of which are noticeably different from the lobed foliage of genera in the tribe Detarieae sensu lato Polhill of Leguminosae, as well as in Apocynaceae, Convolvulaceae, Liriodendraceae, Oxalidaceae, Passifloraceae, Proteaceae Juss., and Zygophyllaceae (see Figure 3; 

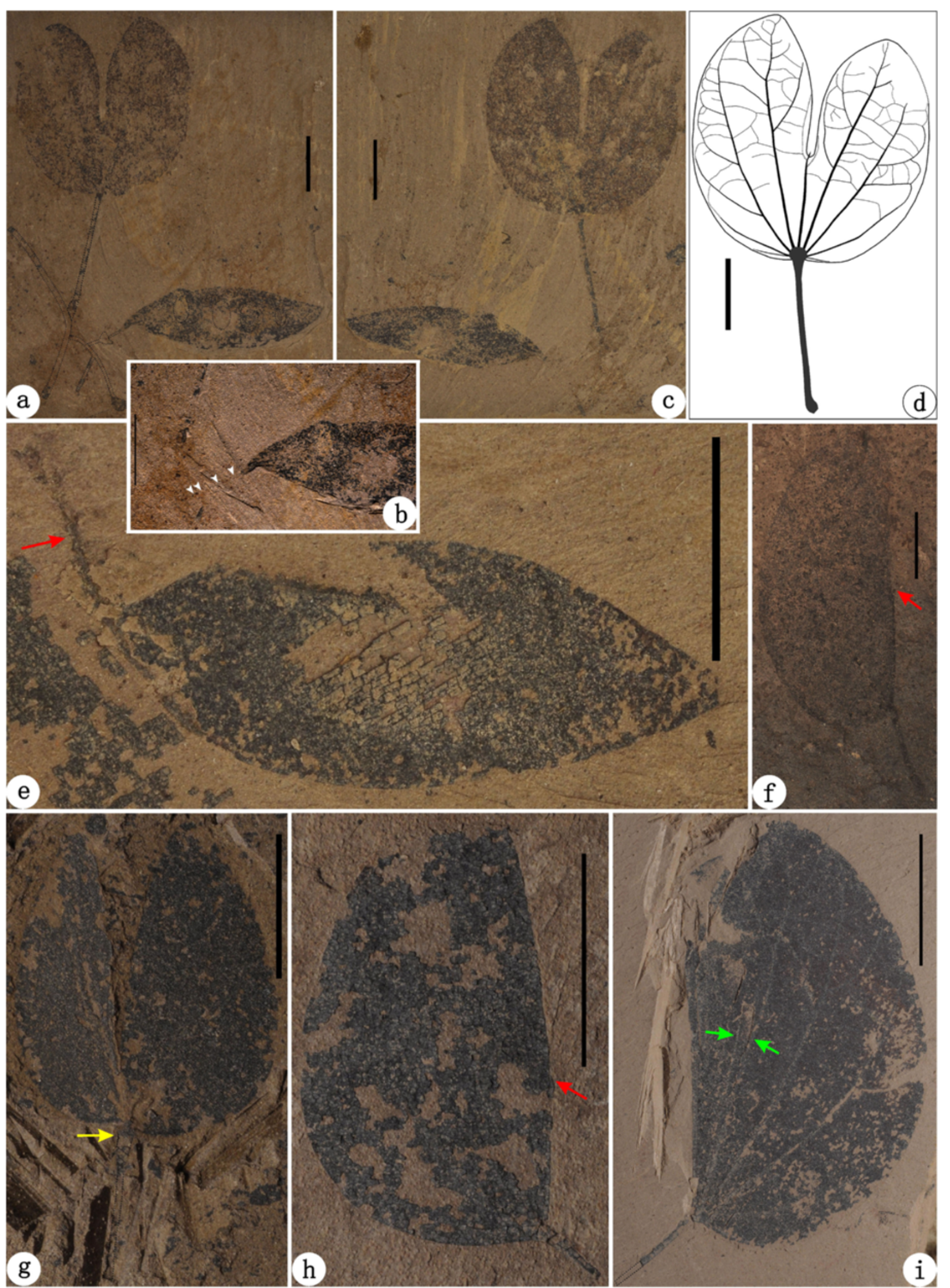

Figure 8 (See legend on next page.) 
Additional file 3). The simple, unlobed leaves of Bauhinia also differ from those of Cercis in the tribe Cercideae in the former usually bearing fewer and weaker secondary veins along the distal third of the midvein and a mucro or spine at the leaf tip [59]. Based upon an extensive review on the previously reported Bauhinia and other similar foliage from the Cretaceous and Cenozoic, those preOligocene reports regarding Bauhinia across the world are either questionable or have been rejected (see Additional file 4). Besides the reliable fossils from Ningming of China, foliage and/or wood of Bauhinia have been described from the Miocene-Pliocene of Thailand, India, Nepal, Uganda, and Ecuador.

\section{Key to the fossil species of Bauhinia from Ningming}

1. Lateral primary veins approach to the margin; secondary veins eucamptodromous-_-__-_-_-_Bauhinia cheniae sp. nov.

1. Lateral primary veins do not approach to the margin; secondary veins brochidodromous-- - -2

2. Bilobate, bifid to ca. $1 / 2$ to $3 / 5$ of laminar length-_-_-_-_-_Bauhinia larsenii D.X. Zhang et Y.F. Chen emend.

2. Bifoliolate, bifid to laminar base-Bauhinia ningmingensis sp. nov.

\section{Systematics}

Family Leguminosae Juss.

Subfamily Caesalpinioideae DC.

Tribe Cercideae Bronn

Subtribe Bauhiniinae (Benth.) Walp.

Genus Bauhinia L.

Type Bauhinia divaricata L.

\section{Fossil species}

Three fossil species of Bauhinia are described as follows. All the voucher specimens were collected from the same locality and stratigraphy, and they are deposited at the same museum.

\section{Type locality}

Ningming County, Guangxi Zhuang Autonomous Region, South China (Figure 2).

\section{Stratigraphic horizon and age}

Ningming Formation, Oligocene.

\section{Repository}

Natural History Museum of Guangxi (NHMG), Nanning, P.R. China.

Bauhinia ningmingensis Qi Wang, Z. Q. Song, Y. F. Chen, S. Shen et Z. Y. Li, sp. nov. (Figure 5a-e).

\section{Etymology}

The specific epithet is derived from Ningming County, where the fossils were collected.

\section{Holotype}

NHMG 011654 (Figure 5b-e) (designated here).

\section{Paratypes}

NHMG 011655 (Figure 5a) (designated here).

\section{Diagnosis}

Small, bifoliolate leaves. Leaflets pulvinate and laminae strongly asymmetrical, obliquely ovate or slightly falcate. Leaflet apexes obtuse. Bases wide cuneate or slightly concave. Margin entire. Primary veins basal acrodromous (3-4 in number) and curved on the exmedial side, not reaching the leaflet margin. Secondary veins brochidodromous. Tertiary veins percurrent or ramified, straight, convex or sinuous. Quaternary veins forming irregular polygons. Aerolation well developed. Freely ending veinlets mostly branching once. Marginal ultimate veins looped and fimbriate.

\section{Description}

Bifoliolate leaves inferred from the symmetry of individual leaflets. Leaflet laminae strongly asymmetrical, obliquely ovate or slightly falcate (Figure $5 \mathrm{a}-\mathrm{c}$ ), ca. $4.0-5.3 \mathrm{~cm}$ long and $2.0-2.6 \mathrm{~cm}$ wide, with partially preserved pulvinate tissue, ca. $2.5 \mathrm{~mm}$ long, showing some horizontal striations (Figure 5c,e). The petiole not preserved. Texture apparently membranous to chartaceous. Leaflet apexes obtuse (Figure 5b,d). Bases wide cuneate or slightly concave (Figure 5a-c,e). Margin entire. Primary veins basal acrodromous, 3-4 in number. Innermost primary veins straight or curved, extremely approaching to the leaflet margin at the base and reaching the leaflet apex. Primary veins on the exmedial side curved, connecting with secondary veins to form a series of arches and loops, not reaching the leaflet margin (Figure 5a-c). Outermost primary veins shorter and weaker. Secondary veins brochidodromous, 
diverging at ca. $60^{\circ}-90^{\circ}$ from the primary veins on the exmedial side. Tertiary veins alternate and opposite percurrent or ramified, straight, convex or sinuous (Figure 5a-c). Quaternary veins forming irregular polygons. Aerolation well developed. Freely ending veinlets mostly branching once. Marginal ultimate veins looped and fimbriate (Figure 5b-d).

\section{Comparisons}

This fossil new species $B$. ningmingensis is very similar to living $B$. madagascariensis subsp. meridionalis $\mathrm{Du}$ Puy et R. Rabev. [46] and B. didyma L. Chen [3,5,41] (Figure 31; see Additional file 3), which are distributed in southeastern Madagascar and southern China, Myanmar, northern Thailand, respectively. However, it noticeably bears much larger leaflets (ca. 4.0-5.3×2.0$2.6 \mathrm{~cm}$ ) than those of the two living species (ca. 0.7-3 $\times$ 04-1.7 $\mathrm{cm}$ and 1.2-2.4 $\times 0.9-1.6 \mathrm{~cm}$ ). In addition, $B$. ningmingensis sp. nov. is different from the previously reported bifoliolate fossil species B. ecuadorensis E.W. Berry [50] and B. siwalika U. Lakh. et N. Awasthi [51] from the Miocene of India and Ecuador in the leaf architectural detail (see Additional files 3 and 4).

Bauhinia cheniae Qi Wang, Z. Q. Song, Y. F. Chen, S. Shen et Z. Y. Li, sp. nov. (Figures 6a-g, 7a-e).

\section{Etymology}

The specific epithet is dedicated to Prof. Chen Dezhao (Chen Te-chao) (South China Botanical Garden, CAS) for her important contribution to the taxonomy of Cercideae.

\section{Holotype}

NHMG 011656a, b (Figure 6a-c) (designated here; part and counterpart specimens).

\section{Paratypes}

NHMG 011657, 011658, 011659 (Figure 6d-g), 011670 (Figure 7a,b), 011671, 011672, 011673 (Figure 7c-e), 011674, 011675, 011660, 011661, 011662, 011663, 011664, 011665, 011666, 011667, 011668, and 011669 (designated here).

\section{Diagnosis}

Small, broadly ovate or suborbicular, moderately or deeply bilobate leaves. Petioles glabrescent or hairy, bearing thicken upper and lower pulvini. Lobe apexes slightly acuminate, obtuse or rounded. Laminar bases shallowly to deeply cordate. Margin entire. Primary veins basal actinodromous, 7-9 in number. The midvein terminated in a short or long spine within a narrow or flaring sinus. Lateral primary veins straight or curved, branched or unbranched, approaching to the margin. Secondary veins eucamptodromous. Intersecondary veins present. Tertiary veins percurrent or ramified, mostly convex, sinuous or rarely straight. Quaternary veins percurrent, forming irregular polygons. Aerolation well developed. Freely ending veinlets mostly unbranched. Marginal ultimate veins absent.

\section{Description}

Bilobate leaves, wide ovate or suborbicular, ca. $2.0-6.0 \mathrm{~cm}$ long and 2.2-6.5 $\mathrm{cm}$ wide, often folded along the midvein (Figures 6a-c, 7a-e). The petiole glabrescent or covered with dense, spreading hairs (Figure $6 \mathrm{~d}, \mathrm{e})$. The petiole stout, ca. 1.6-2.0 cm long, bearing thickened, upper and lower pulvini (Figures 6d,e 7c). The upper pulvinus connecting the laminar base via a tiny, semicircular laminar joint. Bifid to ca. $2 / 3-4 / 5$ of laminar length or almost to the laminar base, forming a narrow or flaring sinus. Two lobes symmetrical or slightly asymmetrical. Lobe apex slightly acuminate, obtuse or rounded (Figures 6a-d,f and 7a-e). Laminar base symmetrical, shallowly to deeply cordate (Figures 6a-d,f,g, 7a-e). Margin entire. Texture apparently chartaceous. Primary veins basal actinodromous, 7-9 in number, the outmost pair and midvein being weaker than the inner pairs. Midvein terminated in a short or long spine within the sinus (Figures 6g, 7c). Lateral primary veins straight or curved, branched or unbranched, and the innermost pair reaching the lobe apex and outer pairs approaching to the margin. Secondary veins eucamptodromous, diverging at ca. $30^{\circ}-80^{\circ}$ mainly from the innermost and outmost lateral primary veins and arching upward along the margin (Figures 6a-c,f,g, 7a,b). A pair of secondary veins usually emitting from the midvein near the sinus and approaching to the inner margin of lobes (Figure $6 b-d, f$ ). Intersecondary veins sometimes present, parallel to subjacent secondary veins. Tertiary veins alternate and opposite percurrent or ramified, mostly convex, sinuous or rarely straight. Quaternary veins alternate and opposite percurrent, forming irregular polygons (Figures 6b,c,g, 7a,b). Aerolation well developed. Freely ending veinlets mostly unbranched. Marginal ultimate veins absent.

\section{Comparisons}

This fossil new species $B$. cheniae is very similar to living $B$. variegata L. (Figure $3 \mathrm{~m}$ ) and B. purpurea L. [3,5,41] in having deeply bilobate leaves and eucamptodromous secondary veins, but it differs from the extant species in having the fewer primary veins and a densely hairy petiole (see Additional file 3). In these respects, B. cheniae sp. nov. is also different from the previously reported, bilobate leafed fossil species $B$. larsenii D.X. Zhang et Y. F. Chen [33], B. krishnanunnii A.K. Mathur et al. [52], B. ramthiensis Antal et N. Awasthi [53], B. nepalensis N. Awasthi et N. Prasad [55], Bauhinia sp. 1 [56], Bauhinia sp. 2 [54], and B. waylandii R.W. Chaney [57] from the Miocene-Pliocene of India, Nepal, Thailand, and Uganda (see Additional files 3 and 4). 
Bauhinia larsenii D.X. Zhang et Y. F. Chen emend. Qi Wang, Z. Q. Song, Y. F. Chen, S. Shen et Z. Y. Li (Figure 8a-i).

Bauhinia larsenii D.X. Zhang et Y. F. Chen, see Chen and Zhang in Bot. J. Linn. Soc. 147: 439, Figures 1, 2, 3, 5 and 6, 2005.

\section{Holotype}

NHMG 45003 (Figure 8a,b herein) (first designated and illustrated by Chen and Zhang [33]: Figure 1]).

\section{Paratypes}

NHMG 45004 (counterpart specimen of holotype; first figured herein, Figure 8c,d), 45012 and 45019 (first designated and illustrated by Chen and Zhang [33]: Figures 2 and 6; Figure 8f,e herein).

\section{Other specimens examined herein}

NHMG 011676, 011678, 011677 (Figure 8g-i), and 011679.

\section{Emended description}

Leaves suborbicular or slightly ovate to wide ovate, ca. 2.1-4.5 cm long and 1.8-4.8 cm wide, usually folded along the midvein (Figure $8 \mathrm{a}-\mathrm{d}, \mathrm{f}-\mathrm{i}$ ). Bifid to ca.1/2-3/5 of laminar length, forming a narrow sinus. Two lobes symmetrical or slightly asymmetrical. Lobe apex rounded to obtuse (Figure 8a,c,d,f). Laminar base symmetrical, rounded or shallowly cordate (Figure 8a,c,d,g). Margin entire. Texture apparently chartaceous to coriaceous. Primary veins basal actinodromous, 5-9 in number, the outmost pair being weaker than the midvein and inner pairs. Midvein terminated in a short spine within the sinus. Lateral primary veins branched or unbranched, and the innermost pair reaching the lobe apex. Major secondary veins brochidodromous, diverging at ca. $45^{\circ}-60^{\circ}$ from the lateral primary veins mainly on the exmedial side and sporadically on the admedial side (Figure 8d). A pair of minor secondary veins emitting from the midvein near the sinus and approaching to the inner margin of lobes (Figure 8d). Secondary veins fused with each other or the branches of primary veins to form loops near the leaf margin, or arcs between the primary veins. Tertiary veins alternate and opposite percurrent or ramified, convex or sinuous. Quaternary veins alternate percurrent. Marginal ultimate veins looped and fimbriate (Figure 8d). Other higher-order veins invisible. The petiole, ca. $1.0-2.2 \mathrm{~cm}$ long, with an upper pulvinus and a lower pulvinus (Figure 8a,c,d,f-i). The upper pulvinus thickened, connecting the laminar base via a tiny, semicircular laminar joint. The lower pulvinus slightly thickened, attached at a curved vegetative shoot at ca. $45^{\circ}$. Not far from the lower pulvinus, a fruit attached on the shoot (Figure 8a-c). The pedicel, ca. $0.2 \mathrm{~cm}$ long, with an inferior perianth scar and a fruit, indicating the flower of its parent plant hypogynous (Figure 8a). The fruit elliptic, ca. 2.8-3.5 cm long and 1.0-1.1 cm wide, with a slightly curved, acuminate base and an acute apex (Figure $8 \mathrm{a}-\mathrm{c}, \mathrm{e})$. The fruit base bearing a thin stipe, ca. 0.4-0.8 cm long (Figure 8e). The suture slightly thickened and non-winged. Carbonaceous remnants with an oblique orientation on the valve surface (Figure 8e) implying the fruit unilocular, possibly coriaceous in texture, and tardily dehiscent. Seeds, about 2-4 in number in a fruit, grossly elliptic or oblong in contour (Figure 8a-c), ca. 0.3-0.6 cm long and $0.2-0.3 \mathrm{~cm}$ wide, oriented with their length perpendicular to the fruit length.

\section{Comparisons}

This fossil species $B$. larsenii was first described by Chen and Zhang [27] on the basis of four specimens. Here, we emended this species, especially regarding the leaf architecture and fruit morphology, based upon the type specimens and newly collected materials. It is very similar to living B. viridescens Desv. and B. brachycarpa Wall. ex Benth. $[3,5,41]$ in bearing shallowly or moderately bilobate leaves, brochidodromous secondary vein, and elliptic fruits (see Additional file 3). However, no adequate characters guarantee the fossils to belong to any living species. In addition, B. larsenii is different from $B$. cheniae sp. nov. and other fossil species [33,50-57] in the leaf architectural detail (see Additional files 3 and 4). In particular, B. larsenii represents the first recognition of Bauhinia fruit and foliage organically connected in the fossil record.

\section{Discussion}

The Leguminosae is the third largest angiosperm family only after Orchidaceae Juss. and Asteraceae Bercht. et J. Presl, varying in habit from herbs to shrubs, vines, lianas, and trees, with an extremely high diversity of ca. 751 living genera and ca. 19,500 species [10,17] across different habitats of the world. Meanwhile, this family has an abundant and diverse fossil record, and its characteristic fruits, flowers, pollen, foliage, and wood have been well recognized from numerous Cenozoic localities around the world $[65,66]$. However, an outstanding incongruence between the palaeobotanical finds and molecular systematics of legumes is that the earliest fossil record of the tribe Cercideae as sister to all other lineages in the molecular phylogenetic trees of Leguminosae [9-14,20-24] has so far occurred later than that of some derived tribes bearing compound leaves such as Sophoreae Spreng. ex DC. in the subfamily Papilionoideae L. ex DC. [67]. Such an incongruence implies that the extant Cercideae bearing the simple, entire or bilobate to bifoliolate foliage is unlikely to be the most primitive in Leguminosae, but the derived as some authors formerly suggested from 
an extinct legume ancestor possibly with palmately compound leaves [68] or pinnately compound leaves [27,69]. The fossil record of the Cercideae lacking or being fewer than those derived tribes in the early Palaeogene of middle latitudes is because either the early distribution of the Cercideae might be restricted to low latitudes, or palaeobotanical studies on the coeval legumes from low latitudes are relatively inadequate [70]. Hence, the Cercideae fossils, especially from low latitudes, can provide an historical perspective for their early evolution, adaptive radiation, and biogeographic history.

Leaves of Cercis have been reported from Late Cretaceous and Cenozoic sediments, but the overwhelming majority of these reports have been rejected, questioned, revised $[59,71]$, or in need of confirmation by reinvestigation of the original materials and discovery of better preserved materials [69] (see Additional file 4). The oldest reliable fossils of Cercis are represented by the foliage and/or fruits (i.e., C. parvifolia Lesq., C. herbmeyeri $\mathrm{H}$. Jia et Manchester) from the Late Eocene Florissant Formation, Colorado and John Day Formation, Oregon, western USA [71,72]. In contrast, the foliage fossils of Bauhinia have been previously reported from the Late Cretaceous and Palaeogene of North America and Eurasia [73-88], but these identifications are erroneous or unreliable [70] (see Additional file 4). Although Bauhinia or Bauhinia-like bilobate foliage have been recently reported from the middle Eocene of Tanzania [89], the late Eocene of Vietnam [30], the late Eocene-early Miocene of Brazil [90], and possibly the latest Oligocene-mid-late Miocene of Australia [91], the preservation of these pre-Miocene fossils, which are observed from the originally published figures, appears too poor to reliably assign these leaf fossils to either Bauhinia or even Cercideae, because neither the pulvinus nor basal actinodromous or acrodromous venations can be confirmed (see Additional file 4). Instead, the oldest reliable evidence of Bauhinia and Bauhinia-like foliage are provided from the Oligocene Ningming Formation, Guangxi, South China (i.e., Bauhinia ningmingensis sp. nov., B. cheniae sp. nov., and B. larsenii D. X. Zhang et Y. F. Chen [33], this paper) and Coatzingo Formation, Puebla, Mexico (i.e., Bauhcis moranii Calvillo-Canadell et Cevallos-Ferriz [92]). By the Miocene-Pliocene, various species of Bauhinia have existed in Thailand, India, Nepal, Uganda, and Ecuador (Figure 4) while those of Cercis have become widespread in mid-latitudes of the northern hemisphere $[69,71]$.

In addition, some other unifoliolate or bilobate foliage or fruit fossils from the Oligocene-Miocene of Jinggu (Yunnan), Zhangpu (Fujian), and Ningming (Guangxi) in South China have been reliably described [93-95] or preliminarily identified as Cercis and Bauhinia (Unpublished observation by Qi Wang, Institute of Botany, Beijing, October $\left.18^{\text {th }}, 2013\right)$. Also, the bilobate foliage extremely similar to Bauhinia has been discovered from the Eocene Oligocene coals of West Sumatra, western Indonesia (vide the image of this leaf fossil and information provided by Drs. Yahdi Zaim, Institute of Technology, Bandung, Indonesia, Peter Wilf, Pennsylvania State University, and Gregg F. Gunnell, Duke University Lemur Center, March $17^{\text {th }}$ 2014). Hence, more Cercideae fossil will be studied and reported from low-latitude tropical zone [96] of East and Southeast Asia. Recently, a strictly east-towest vicariance for the historical biogeography of Cercis has been postulated by molecular data [97]. The Cercideae macrofossils occurring in the Eocene to Oligocene of mid-low latitudes and apparently lacking in the coeval sediments at high-latitudes appear to partially support a tropical Tethys Seaway origin and spread $[11,22,23]$ or an "Out-of-Tropical Asia" dispersal [26] of the Cercideae and the Leguminosae as formerly hypothesized by some authors. However, detailed historical biogeography of Cercideae still need more palaeobotanical and molecular dataset.

\section{Conclusions}

Bauhinia has exhibited a certain diversity with three species (i.e., B. ningmingensis, B. cheniae, and B. larsenii) bearing bifoliolate or bilobate leaves in a low-latitude localityNingming since at least the Oligocene, implying the tropical zone of South China may represent one of the centres for early diversification of the genus. The reliable macrofossils of Bauhinia and Cercis have made their debut in the Eocene-Oligocene floras from mid-low latitudes and appeared to lack in the coeval floras at high latitudes. By the Miocene-Pliocene, various species of Bauhinia have existed in Thailand, India, Nepal, Uganda, and Ecuador while those of Cercis have become widespread in mid-latitudes of the northern hemisphere. Such a biogeographic pattern implies a possible Tethys Seaway origin and spread for legumes. However, detailed scenarios for the historical biogeography of Bauhinia and its relatives still need more robust dataset from palaeobotany and molecular phylogeny in future research.

\section{Additional files}

Additional file 1: The distribution of living species in Bauhinia $\mathrm{L}$.

Additional file 2: Information on voucher specimens used in this study.

Additional file 3: Comparisons between Bauhinia species and other taxa with similar foliage.

Additional file 4: Previously described fossils assignable or similar to Bauhinia L.

Competing interests

The authors declare that they have no competing interests. 


\section{Authors' contributions}

ZYL, YFC, QW, and SS conducted data analyses, taxonomic treatments, and evolutionary and biogeographic interpretations. QW and ZQS photographed specimens, illustrated the line-drawings, and arranged the figures. QW wrote the manuscript and formatted the text. All authors read and approved the final manuscript.

\section{Acknowledgements}

We greatly thank two anonymous reviewers for their useful comments and suggestions. Dr. Chen Gengjiao, Mr. Xie Zhiming and other colleagues, Natural History Museum of Guangxi, Nanning for assistance in the field. Dr. Shi Gongle, Nanjing Institute of Geology and Palaeontology, CAS, Nanjing, Dr. Steven R. Manchester, Florida Museum of Natural History, Gainesville, Dr. Yahdi Zaim, Institute of Technology, Bandung, Dr. Peter Wilf, Pennsylvania State University, and Dr. Gregg F. Gunnell, Duke University Lemur Center, Durham for providing us with unpublished images, manuscripts, and thesis. Mrs. Anna Pavlova, National Institute of Carpology, Moscow, Dr. Yulia V. Mosseichik, Geological Institute of the Russian Academy of Sciences, Moscow, Dr. Boris I. Pavlyutkin, Far East Geological Institute, Vladivostok, Prof. Martin Pickford, Muséum National d'Histoire Naturelle, Paris, Dr. Mike Pole, University of Tasmania, Hobart, Prof. Rakesh C. Mehrotra, Birbal Sahni Institute of

Palaeobotany, Lucknow, Prof. Subir Bera, University of Calcutta, Kolkata, Dr. Silvia N. Césari, Museo Argentino de Ciencias Naturales "Bernardino Rivadavia", Buenos Aires, Prof. Vladan Radulović, University of Belgrade, Belgrade, Dr. Huang Junhua, Xinjiang Agricultural University, Urumqi, Dr. Yang Yong, Institute of Botany, CAS, Beijing, and Dr. Xue Jinzhuang, Peking University, Beijing for providing us with some key references. Mr. Zong Ruiwen, China University of Geosciences, Wuhan for graphing Figure 2. Mr. Sun Yingbao, Institute of Botany, CAS for offering a world base map in Figure 4. This work was supported by the National Natural Science Foundation of China (nos. 41372029 and 41162002), the State Key Laboratory of Systematic and Evolutionary Botany, CAS (no. 56176G1044), and the State Key Laboratory of Palaeobiology and Stratigraphy, Nanjing Institute of Geology and Palaeontology, CAS (no. 123106) to QW, ZYL and YFC.

Received: 19 January 2014 Accepted: 13 April 2014 Published: 24 April 2014

\section{References}

1. Wunderlin RP, Larsen K, Larsen SS: Cercideae Bronn (1822). In Advances in legume systematics, part 1. Edited by Polhill RM, Raven PH. Kew: The Royal Botanic Gardens; 1981:107-116.

2. Wunderlin RP, Larsen K, Larsen SS: Reorganization of the Cercideae (Fabaceae: Caesalpinioideae). Biol Skr 1987, 28:1-40.

3. Chen TC: Bauhinia Linn. In Flora Reipublicae Popularis Sinicae, Tomus 39. Edited by Wu TL, Chen PY, Wei CF, Chen TC. Beijing: Science Press; 1988:145-203.

4. Lewis G, Forest F: Tribe Cercideae. In Legumes of the world. Edited by Lewis G, Schrire B, Mackinder B, Lock M. Kew: The Royal Botanic Gardens; 2005:57-68.

5. Chen TC, Zhang DX, Larsen K, Larsen SS: Bauhinia Linnaeus. In Flora of China, vol. 10. Edited by Wu ZY, Raven PH, Hong DY. Beijing: Science Press \& St. Louis: Missouri Botanical Garden Press; 2010:6-21.

6. Wunderlin RP: Reorganization of the Cercideae (Fabaceae: Caesalpinioideae). Phytoneuron 2010, 48:1-5.

7. Zhang DX: Leaf venation of Cercideae (Leguminosae). J Trop Subtrop Bot 1994, 2:45-57.

8. Zhang DX: A cladistic analysis of Bauhinia L. (Leguminosae). Chin J Bot 1995, 7:52-64

9. Hao G, Zhang DX, Zhang MY, Guo LX, Li SJ: Phylogenetics of Bauhinia subgenus Phanera (Leguminosae: Caesalpinioideae) based on ITS sequences of nuclear ribosomal DNA. Bot Bull Acad Sin 2003, 44:223-228.

10. LPWG (the Legume Phylogeny Working Group): Legume phylogeny and classification in the $21^{\text {st }}$ century: Progress, prospects and lessons for other species-rich clades. Taxon 2013, 62:217-248.

11. Sinou C, Forest F, Lewis GP, Bruneau A: The genus Bauhinia s. I. (Leguminosae): a phylogeny based on the plastid trnL-trnF region. Botany 2009, 87:947-960.

12. Santos FDARD, Novaes DDM, Queiroz LPD: Pollen of Bauhinia L. and Phanera Lour. (Leguminosae-Caesalpinioideae) from the Brazilian Caatinga. Amer J PI Sci 2012, 3:909-920.
13. Banks H, Forest F, Lewis G: Palynological contribution to the systematics and taxonomy of Bauhinia s. I. (Leguminosae: Cercideae). S African J Bot 2013, 89:219-226.

14. Anju J, Manodeep C, Jagdish K: Bauhinia tomentosa: a phytopharmacological review. Int Res J Pharm 2011, 2:128-131.

15. Kumar T, Chandrashekar KS: Bauhinia purpurea Linn.: A review of its ethnobotany, phytochemical and pharmacological profile. Res J Med PI 2011, 5:420-431.

16. Zhang YQ, Xu W, Li H, Chen LD, Chu KD: Some progress in Bauhinia championi (Benth.) Benth. of Chinese herbal medicines. Asia-Pacific Tradit Med 2012, 8:207-209.

17. LPWG (the Legume Phylogeny Working Group): Towards a new classification system for legumes: Progress report from the $6^{\text {th }}$ International Legume Conference. S African J Bot 2013, 89:3-9.

18. Bruneau A, Forest F, Herendeen PS, Klitgaard BB, Lewis GP: Phylogenetic relationships in the Caesalpinioideae (Leguminosae) as inferred from chloroplast trnL intron sequences. Syst Bot 2001, 26:487-514.

19. Bruneau A, Mercure M, Lewis GP, Herendeen PS: Phylogenetic patterns and diversification in the caesalpinioid legumes. Botany 2008, 86:697-718.

20. Doyle JJ, Luckow MA: The rest of iceberg: legume diversity and evolution in a phylogenetic context. Pl Physiol 2003, 131:900-910.

21. Wojciechowski MF, Lavin M, Sanderson MJ: A phylogeny of legumes (Leguminosae) based on analysis of the plastid matK gene resolves many well-supported subclades within the family. Amer J Bot 2004, 91:1846-1862.

22. Lewis G, Schrire B, Mackinder B, Lock M: Legumes of the world. Kew: The Royal Botanic Gardens; 2005:1-577.

23. Schrire $B D$, Lavin M, Lewis GP: Global distribution patterns of the Leguminosae: insights from recent phylogenies. Biol Skr 2005, 55:375-422

24. Lavin M, Herendeen PS, Wojciechowski MF: Evolutionary rates analysis of Leguminosae implicates a rapid diversification of lineages during the Tertiary. Syst Biol 2005, 54:575-594.

25. Van der Pijl L: The leaf of Bauhinia. Acta Bot Neerl 1952, 1:287-309.

26. Cusset G: Essai d'une Taxinomie Foliaire dans la Tribu des Bauhinieae. Adansonia, N S 1966, 6:251-280.

27. Owens SA: Secondary and tertiary pulvini in the unifoliate leaf of Cercis canadensis L. (Fabaceae) with comparison to Bauhinia purpurea L. Int J PI Sci 2000, 161:583-597.

28. Kuang GD, Chen GJ, Chen YF, Huang ZT: New information on the Tertiary biostratigraphy of the Ningming Basin, Guangxi. J Stratigr 2004, 28:362-367.

29. Liu GW, Yang RY: Pollen assemblages of the Late Eocene Nadu Formation from the Bose Basin of Guangxi, Southern China. Palynology 1999, 23:97-114.

30. Böhme M, Aiglstorfer M, Antoine P-O, Appel E, Havlik P, Métais G, Phuc LT, Schneider S, Setzer F, Tappert R, Tran DN, Uhl D, Prieto J: Na Duong (northern Vietnam)-an exceptional window into Eocene ecosystems from Southeast Asia. Zitteliana A 2013, 53:121-167.

31. Li HM, Chen YF, Chen GJ, Kuang GD, Huang ZT: Tertiary fossil winged fruits of Palaeocarya from Ningming of Guangxi. S China Acta Palaeontol $\sin$ 2003, 42:537-547.

32. Wang WM, Chen GJ, Chen YF, Kuang GD: Tertiary palynostratigraphy of the Ningming basin, Guangxi. J Stratigr 2003, 27:324-327.

33. Chen YF, Zhang DX: Bauhinia larsenii, a fossil legume from Guangxi, China. Bot J Linn Soc 2005, 147:437-440.

34. Chen GJ, Fang F, Chang MM: A new cyprinid closely related to cultrins + xenocyprinins from the Mid-Tertiary of South China. J Vertebr Paleontol 2005, 25:492-501.

35. Chen GJ, Chang MM: A new cyprinin from Oligocene of South China. Sci China Earth Sci 2011, 54:481-492.

36. Shi GL: Fossil plants from the Oligocene Ningming Formation of Guangxi, and a preliminary palaeoclimatic reconstruction of the flora. Nanjing, China: Ph.D. thesis. Nanjing Institute of Geology and Palaeontology, Chinese Academy of Sciences; 2010:1-218.

37. Shi GL, Zhou ZY, Xie ZM: A new Cephalotaxus and associated epiphyllous fungi from the Oligocene of Guangxi, South China. Rev Palaeobot Palynol 2010, 161:179-195.

38. Shi GL, Zhou ZY, Xie ZM: Cupressus foliage shoots and associated seed cones from the Oligocene Ningming Formation of Guangxi, South China. Rev Palaeobot Palynol 2011, 166:325-334.

39. Shi GL, Zhou ZY, Xie ZM: A new Oligocene Calocedrus from South China and its implications for transpacific floristic exchanges. Amer J Bot 2012, 99:108-120 
40. efloras.org. St. Louis: Missouri Botanical Garden \& Cambridge: Harvard University Herbaria. Published on the Internet [http://www.efloras.org/] (accessed 9 May 2014)

41. Chinese Virtual Herbarium(CVH): A National Taxonomic Database. Beijing: Institute of Botany, Chinese Academy of Sciences. Published on the Internet [http://v5.cvh.org.cn/] (accessed 15 April 2014).

42. International Legume Database \& Information Service (ILDIS. Cardiff: Cardiff School of Computer Science \& Informatics. Published on the Internet [http://www.ildis.org/] (accessed 15 April 2014).

43. Hunt Institute for Botanical Documentation. Pittsburgh: Hunt Library Carnegie Mellon University. Published on the internet [http://huntbot.andrew.cmu. edu/HIBD/Departments/Databases.shtml] (accessed 15 April 2014).

44. Johnson KR: Description of seven common fossil leaf species from the Hell Creek Formation (Upper Cretaceous: Upper Maastrichtian), North Dakota, South Dakota, and Montana. Proc Denver Mus Nat Hist, Ser 3 1996, 12:1-47.

45. Dilcher DL, Crane PR: Archaeanthus: An early angiosperm from the Cenomanian of the western Interior of North America. Ann Missouri Bot Gard 1984, 71:351-384

46. Du Puy DJ, Labat JN, Rabevohitra R, Villiers JF, Bosser J, Moat J: The Leguminosae of Madagascar. Kew: The Royal Botanic Gardens; 2002:1-737.

47. Palmer E, Pitman N: Trees of southern Africa, vol. 2. Cape Town A. A: Balkema; 1972:705-1497.

48. Brenan JPM: Leguminosae subfamily Caesalpinioideae. In Flora of Tropical East Africa. Edited by Milne-Redhead E, Polhill RM. London: Crown Agents for Oversea Governments and Administrations; 1967:1-230.

49. Wieringa JJ: Monopetalanthus exit. A systematic study of Aphanocalyx, Bikinia, Icuria, Michelsonia and Tetraberlinia (Leguminosae,

Caesalpinioideae). Wageningen Agric Univ Pap 1999, 99(4):1-320.

50. Berry EW: Fossil floras from southern Ecuador. Johns Hopkins Univ Stud Geol 1945, 14:93-150.

51. Lakhanpal RN, Awasthi N: A late Tertiary forule from near Bhikhnathoree in West Champaran District, Bihar. In Proceedings of the symposium on evolutionary botany and biostratigraphy. Current Trends in Life Sciences 10 (A. K. Ghosh Commemoration Volume). Edited by Sharma AK, Mitra GC, Banerjee M. New Delhi: Today and Tomorrow's Printers \& Publishers; 1984:587-596.

52. Mathur AK, Mishra VP, Mehra S: Systematic study of plant fossils from Dagshai, Kasauli and Dharmsala formations of Himachal Pradesh. Geol Surv India, Palaeontol Indica, N S 1996, 50:1-121.

53. Antal JS, Awasthi N: Fossil flora from the Himalayan foot-hills of Darjeeling District, West Bengal, India and its palaeoecological and phytogeographical significance. Palaeobotanist 1993, 42:14-60.

54. Bande MB, Srivastava GP: Late Cenozoic plant-impressions from Mahuadnar Valley, Palamu District, Bihar. Palaeobotanist 1990, 37:331-366

55. Awasthi N, Prasad M: Siwalik plant fossils from Surai Khola area, western Nepal. Palaeobotanist 1990, 38:298-318.

56. Endo S, Fujiyama I: Some Late Mesozoic and Late Tertiary plants and a fossil insect from Thailand. In Contributions to the geology and palaeontology of Southeast Asia 31, geology and palaeontology of Southeast Asia, volume 2. Edited by Kobayashi T, Toriyama R. Tokyo: University of Tokyo Press; 1966:191-197.

57. Chaney RW: A Tertiary flora from Uganda. J Geol 1933, 41:702-709.

58. Ellis B, Daly DC, Hickey LJ, Johnson KR, Mitchell JD, Wilf P, Wing SL: Manual of leaf architecture. Ithaca \& New York: Cornell University Press; 2009:1-190.

59. Owens SA, Fields PF, Ewers FW: Degradation of the upper pulvinus in modern and fossil leaves of Cercis (Fabaceae). Amer J Bot 1998, 85:273-284.

60. Walker JD, Geissman JW, Bowring SA, Babcock LE: The Geological Society of America Geologic Time Scale. Geol Soc Amer Bull 2013, 125:259-272.

61. Scotese CR: A continental drift flipbook. J Geol 2004, 112:729-741.

62. Brummitt RK, Powell CE: Authors of plant names. Kew: The Royal Botanic Gardens; 1992:1-732.

63. Botanico-Periodicum-Huntianum (BPH). Pittsburgh: Hunt Library Carnegie Mellon University. Published on the internet [http://fmhibd.library.cmu.edu/ fmi/iwp/cgi?-db=BPH_Online\&-loadframes] (accessed 15 April 2014).

64. Index Herbariorum. Bronx: The New York Botanical Garden. Published on the internet [http://sweetgum.nybg.org/ih/] (accessed 15 April 2014).

65. Herendeen PS, Dilcher DL: Advances in legume systematics, part 4, the fossil record. Kew: The Royal Botanic Gardens; 1992:1-326.

66. Wang Q: Nomenclatural notes on Leguminosites and several taxonomically relevant names (fossil Leguminosae). Taxon 2012, 61:871-877.
67. Crepet WL, Herendeen PS: Papilionoid flowers from the Early Eocene of southeastern North America. Edited by Herendeen PS, Dilcher DL. In Advances in Legume Systematics: 4. The Fossil Record. Kew: The Royal Botanic Gardens; 1992:43-55.

68. Watari S: Anatomical studies on some leguminous leaves with special reference to the vascular system in petioles and rachises. J Fac Sci Imp Univ Tokyo, Sect 3 Bot 1934, 4:225-365.

69. Wang Q: Pulvini of Cercis leaves from the Miocene Shanwang Formation of Shandong Province and the early evolution of the pulvinus in Leguminosae. Acta Palaeontol Sin 2012, 51:1-13.

70. Herendeen PS, Crepet WL, Dilcher DL: The fossil history of the Leguminosae: phylogenetic and biogeographic implications. In Advances in legume systematics, part 4, the fossil record. Edited by Herendeen PS, Dilcher DL. Kew: The Royal Botanic Gardens; 1992:303-316.

71. Jia H, Manchester SR: Fossil leaves and fruits of Cercis (Leguminosae) from the Eocene of western North America. Int J PI Sci 2014:175. in press (DOI: 10.1086/675693)

72. MacGinitie HD: Fossil plants of the Florissant beds, Colorado. Publ Carnegie Inst Washington 1953, 599:1-198.

73. Newberry JS: Description of a species of Bauhinia from the Cretaceous clays of New Jersey. Bull Torrey Bot Club 1886, 13:77-78.

74. Newberry JS: The flora of the Amboy Clays. Monogr U S Geol Surv 1895, 26:1-260.

75. Berry EW: A new Cretaceous Bauhinia. Torreya 1908, 8:218-219.

76. Berry EW: A new Cretaceous Bauhinia from Alabama. Amer J Sci, Ser 4 1910, 29:256-258.

77. Berry EW: The flora of the Raritan Formation. Bull Geol Surv New Jersey 1911, 3:1-233.

78. Berry EW: Contributions to the Mesozoic flora of the Atlantic Coastal Plain, XI. Tennessee. Bull Torrey Bot Club 1916, 43:283-304.

79. Berry EW: Upper Cretaceous floras of the eastern gulf region in Tennesse, Mississippi, Alabama, and Georgia. U S Geol Surv Profess Pap 1919, 112:1-177.

80. Kryshtofovich AN: On the Cretaceous flora of Russian Sakhalin. J Coll Sci Imp Univ Tokyo 1918, 40:1-73.

81. Kryshtofovich AN: Cretaceous flora of Sakhalin, Mgach and Polovinka. In A. N. Kryshtofovich selected works, tom 2, 1962 (reprinted). Moscow \& Leningrad: Izdatel'stvo Academii Nauk SSSR; 1937:211-289.

82. Brown RW: New items in Cretaceous and Tertiary floras of the western United States. J Washington Acad Sci 1956, 46:104-108.

83. Brown RW: Paleocene flora of the Rocky Mountains and Great Plains. U S Geol Surv Profess Pap 1962, 375:1-119.

84. Shilin PV: On the age of plant-bearing deposits of Taldysaj. Vestnik Akad Nauk Kazakh SSR 1970, 1:57-59.

85. Shilin PV: Late Cretaceous flora of the Beleuty River. Mater Istorii Fauny F/ Kazakhstana 1977, 7:126-139.

86. Shilin PV, Romanova EV: Senonskie flory Kazakhstana (=Senonian flora of Kazakhstan). Alma-Ata: Nauka; 1978:1-176.

87. Tao JR, Xiong XZ: The latest Cretaceous flora of Heilongjiang Province and the floristic relationship between East Asia and North America. Acta Phytotax Sin 1986, 24:1-15

88. Tao JR, Zhou ZK, Liu YS: The evolution of the Late Cretaceous-Cenozoic floras in China. Beijing: Science Press; 2000:1-282.

89. Jacobs BF, Herendeen PS: Eocene dry climate and woodland vegetation in tropical Africa reconstructed from fossil leaves from northern Tanzania. Palaeogeogr Palaeoclimatol Palaeoecol 2004, 213:115-123.

90. Biagolini CH, Bernardes-de-Oliveira MEC, Caramês AG: Itaquaquecetuba Formation, São Paulo basin, Brazil: new angiosperm components of Paleogene taphoflora. Brazil J Geol 2013, 43:639-652.

91. Carpenter RJ, Goodwin MP, Hill RS, Kanold K: Silcrete plant fossils from Lightning Ridge, New South Wales: new evidence for climate change and monsoon elements in the Australian Cenozoic. Austral J Bot 2011 59:399-425.

92. Calvillo-Canadell L, Cevallos-Ferriz SRS: Bauhcis moranii gen. et sp. nov. (Cercideae, Caesalpinioideae), an Oligocene plant from Tepexi de Rodríguez, Puebla, Mexico, with leaf architecture similar to Bauhinia and Cercis. Rev Palaeobot Palynol 2002, 122:171-184.

93. Wang Q, Shen S: Fossil fruits and leaves of Cercis (Leguminosae, Caesalpinioideae) from the Cenozoic of China and their biogeographic implications. Jap J Palynol 2012, 58(Spec Issue):252.

94. WGCPC [abbreviation for "Cenozoic plants from China" Writing Group of Institute of Botany and Nanjing Institute of Geology and Palaeontology, 
Academia Sinica]: Fossil Plants of China, 3 Cenozoic Plants from China. Beijing: Science Press; 1978:1-232.

95. Guo SX, Zhou ZK: The megafossil legumes from China. In Advances in legume systematics, part 4: the fossil record. Edited by Herendeen PS, Dilcher DL. Kew: The Royal Botanic Gardens; 1992:207-223.

96. Zhu H: Geographical elements of seed plants suggest the boundary of the tropical zone in China. Palaeogeogr Palaeoclimatol Palaeoecol 2013, 386:16-22.

97. Fritsch PW, Cruz BC: Phylogeny of Cercis based on DNA sequences of nuclear ITS and four plastid regions: Implications for transatlantic historical biogeography. Molec Phylogen Evol 2012, 60:816-825.

doi:10.1186/1471-2148-14-88

Cite this article as: Wang et al:: Leaves and fruits of Bauhinia (Leguminosae, Caesalpinioideae, Cercideae) from the Oligocene Ningming Formation of Guangxi, South China and their biogeographic implications. BMC Evolutionary Biology 2014 14:88.

\section{Submit your next manuscript to BioMed Central and take full advantage of:}

- Convenient online submission

- Thorough peer review

- No space constraints or color figure charges

- Immediate publication on acceptance

- Inclusion in PubMed, CAS, Scopus and Google Scholar

- Research which is freely available for redistribution 